\title{
Nested clade phylogeographical analysis of the finless porpoise (Neophocaena phocaenoides) inhabiting Chinese and Japanese coasts
}

\author{
L. Li*, J. Jiang*, X. Wang and X. Jiang \\ Key Laboratory of Marine Genetics and Breeding, \\ Ocean University of China, Ministry of Education, Qingdao, China \\ *These authors contributed equally to this study. \\ Corresponding author: X. Wang \\ E-mail: wangxubo@ouc.edu.cn
}

Genet. Mol. Res. 12 (3): 2528-2536 (2013)

Received April 12, 2012

Accepted November 22, 2012

Published February 28, 2013

DOI http://dx.doi.org/10.4238/2013.February.28.20

\begin{abstract}
The finless porpoise (Neophocaena phocaenoides) is a small cetacean whose survival is largely affected by human activity. The characteristics and structures of 3 populations in China and 4 to 5 populations in Japan have been well documented, although their history and origins remain poorly understood. In this study, nested clade phylogeographical analysis was applied to mtDNA sequences from finless porpoises to delineate the historical factors shaping the divergence pattern of this species. The sampling range covered most habitats of the finless porpoise, including the Chinese and Japanese coasts and the Yangtze River. A nested cladogram was constructed, and all 3 (2-step) clades were linked together without interior or tip status. Our data indicated that haplotype $\mathrm{C}$ was the most common among most individuals and populations, which could be the most ancient haplotype among all of the sampled types. As populations expanded to reside in different areas, ancient types with haplotype $\mathrm{C}$ mutated to other haplotypes, which were kept endemic by geological barriers that changed during glacial cycles that retarded gene flow. Populations in Japanese Pacific coasts and inland sea and post-arc marginal seacoasts
\end{abstract}


and the Yangtze River were formed by the residual individuals left when allopatric fragmentation occurred in the ancestral population. The existence of highly endemic haplotypes and high genetic diversity from the Ariake Sound, Tachibana Bay, and the Yellow Sea indicated a relatively isolated state in these areas during the evolutionary history of the finless porpoise. The phylogenetic pattern revealed in the present study provided a better understanding of the biogeographical events that affected the finless porpoise within this region.

Key words: Neophocaena phocaenoides; NCPA; mtDNA; Gene flow

\section{INTRODUCTION}

The finless porpoise (Neophocaena phocaenoides) is a small cetacean that inhabits warm and coastal Indo-Pacific waters ranging from northern Japan to the Persian Gulf, including many rivers in the Asian subcontinent (Jefferson et al., 1993). Human activity greatly affects its survival, and as a result is bringing this animal to the verge of extinction. The finless porpoise has been listed on Appendix I of the Convention on International Trade Endangered Species (Yoshida et al., 2001).

Along the Chinese coast, 3 populations of finless porpoise have been distinguished according to their morphological and anatomical characteristics (Gao and Zhou, 1995a,b,c). The Yellow Sea population inhabits the sea area ranging from the Bohai Sea to the northern portion of the East China Sea; the South China Sea population lives in the southern portion of the East and South China Sea; whereas the Yangtze River population is distributed in the middle and lower reaches of the Yangtze River. Along the Japanese coast, 4 to 5 populations of finless porpoise are identified based on either genetic (Yoshida et al., 2001) or skull morphological differences (Yoshida et al., 1995): the Sendai-Tokyo, Ise-Mikawa, Ariake Sound-Tachibana, and Inland Sea-Hibiki Nada-Omura Bay populations (or Inland Sea-Hibiki Nada and Omura Bay populations; Yoshida et al., 1995). Although the population characteristics and structures of $N$. phocaenoides inhabiting Chinese and Japanese coasts are well documented (Yoshida et al., 2001; Yang et al., 2002; Zheng et al., 2005), their diverse history and origins remain poorly understood.

Previous evidence suggests that the divergence of finless porpoise populations inhabiting Chinese coasts occurred 0.5-1.0 mya (Zheng et al., 2005). The past 1,000,000 years were characterized by a series of large glacial-interglacial changes (Imbrie et al., 1992). The sea level declined 120-140 m during the glacial maxima of this time (Lambeck et al., 2002). Climatic shifts and consequent geographical and oceanographical changes severely and profoundly affected the demographics of marine life (Liu, 2006). The restricted distribution of marine mammals acts to preserve population signatures of historical events; thus, determining the phylogeographic patterns of the finless porpoise may increase our understanding of the biogeography framework of the Northeast Asian coasts.

Nested clade phylogeographical analysis (NCPA) is a widely used method for reconstructing the demographic history of spatially distributed populations from genetic data (Templeton et al., 1995). By testing geographical associations at different hierarchical levels of the estimated gene tree, spatiotemporal inferences can be made regarding evolutionary processes (fragmentation, range expansion, restricted gene flow, etc.; Templeton, 1998) that are 
likely to have contributed to the observed patterns. NCPA has been advantageous for disentangling contributions of historical processes and current gene flow to the observed patterns of haplotype composition. This method has been instrumental in phylogeographical research of humans (Hammer et al., 1998), reptiles (Paulo et al., 2002; Amato et al., 2008), fishes (Weiss et al., 2002), insects (Contreras-Díaz et al., 2003), mollusks (Turner et al., 2000; Wilke and Pfenninger, 2002), coelenterates (Márquez et al., 2002), and plants (Huang and Lin, 2006).

In this study, we mined mtDNA sequence data from previous studies of Chinese and Japanese finless porpoise populations (Yoshida et al., 2001; Yang et al., 2002; Zheng et al., 2005) and integrated these data with sequences that we recently obtained. By using NCPA, we aimed to unveil the historical factors forming the divergence pattern of the finless porpoise in order to achieve a better understanding not only of this species but also of the biogeographical events that occurred in this region, historically.

\section{MATERIAL AND METHODS}

\section{Samples}

A total of 279 finless porpoise mtDNA sequences were available in GenBank. Ten DNA samples from Rongchen in the Shandong Peninsula were amplified using primers described by Zheng et al. (2005). Polymerase chain reaction products were sequenced on ABI 3730 automated DNA sequencers (Applied Biosystems, Foster City, CA, USA). Altogether, this process provided us with mtDNA control region sequences from 289 calves. The GenBank accession numbers and references for the published sequences are AF193543-AF193552 (Yoshida et al., 2001), AF289280-AF289352 (Yang et al., 2002), AF481866, AF481867, AF481869, AF481874, and AF481871 (Zheng et al., 2005). These calves were collected from 17 locations (Table 1, Figure 1) covering all 7 identified populations across the Chinese and Japanese coasts and the Yangtze River, as discriminated by genetic and/or morphological characters (Yoshida et al., 2001; Yang et al., 2002).

Table 1. Variable nucleotides found in the mtDNA control region (344 bp in length) and 16 haplotypes defined.

\begin{tabular}{|c|c|c|c|c|c|c|c|c|c|c|c|c|c|c|c|c|}
\hline \multirow[t]{4}{*}{ Haplotype } & \multirow[t]{4}{*}{ Accession No. } & \multicolumn{15}{|c|}{ Nucleotide position } \\
\hline & & & & & & & 1 & 1 & 1 & 2 & 2 & 2 & 2 & 2 & 2 & 3 \\
\hline & & 4 & 7 & 7 & 7 & 8 & 1 & 5 & 5 & 0 & 2 & 3 & 4 & 5 & 6 & 3 \\
\hline & & 4 & 2 & 3 & 7 & 2 & 7 & 7 & 8 & 2 & 1 & 2 & 2 & 0 & 1 & 4 \\
\hline A & AF193543 & $\mathrm{t}$ & $\mathrm{g}$ & $\mathrm{a}$ & $\mathrm{a}$ & $\mathrm{t}$ & $\mathrm{g}$ & $\mathrm{g}$ & $\mathrm{c}$ & $\mathrm{t}$ & $\mathrm{a}$ & $\mathrm{a}$ & $\mathrm{t}$ & $\mathrm{t}$ & $\mathrm{g}$ & $\mathrm{t}$ \\
\hline B & AF193544 & $\cdot$ & $\cdot$ & · & $\mathrm{g}$ & $\cdot$ & $\cdot$ & . & $\cdot$ & $\cdot$ & g & . & . & . & . & . \\
\hline $\mathrm{C}$ & AF193545 & $\cdot$ & $\cdot$ & . & $\mathrm{g}$ & $\cdot$ & $\cdot$ & . & . & . & . & . & . & · & . & . \\
\hline $\mathrm{D}$ & AF193546 & . & $\cdot$ & $\mathrm{g}$ & $\mathrm{g}$ & $\cdot$ & $\cdot$ & . & . & . & . & . & . & . & . & . \\
\hline E & AF193547 & $\cdot$ & $\cdot$ & $\mathrm{g}$ & $\mathrm{g}$ & $\cdot$ & $\cdot$ & . & . & . & . & . & . & . & . & $\mathrm{c}$ \\
\hline $\mathrm{F}$ & AF193548 & . & $\mathrm{a}$ & . & . & $\cdot$ & $\cdot$ & . & . & . & . & . & . & $\mathrm{c}$ & . & . \\
\hline $\mathrm{G}$ & AF193549 & $\cdot$ & $\mathrm{a}$ & . & $\cdot$ & $\mathrm{c}$ & $\cdot$ & . & . & . & . & . & . & $\mathrm{c}$ & . & . \\
\hline $\mathrm{H}$ & AF193550 & $\cdot$ & $\mathrm{a}$ & . & $\cdot$ & $\cdot$ & $\cdot$ & . & . & . & . & . & $\mathrm{c}$ & $\mathrm{c}$ & . & . \\
\hline I & AF193551 & $\cdot$ & $\cdot$ & $\mathrm{g}$ & $\mathrm{g}$ & $\cdot$ & $\cdot$ & . & . & $\mathrm{c}$ & $\cdot$ & . & $\cdot$ & . & $\cdot$ & . \\
\hline $\mathrm{J}$ & AF193552 & . & $\cdot$ & . & . & $\cdot$ & $\cdot$ & . & . & . & . & . & $\cdot$ & . & $\mathrm{a}$ & . \\
\hline $\mathrm{K}$ & AF289280 & $\cdot$ & $\cdot$ & . & $\mathrm{g}$ & $\cdot$ & $\cdot$ & . & . & . & . & . & $\cdot$ & $\mathrm{c}$ & $\mathrm{a}$ & . \\
\hline $\mathrm{L}$ & AF289281 & $\cdot$ & $\cdot$ & . & $\mathrm{g}$ & $\cdot$ & $\cdot$ & . & $\mathrm{t}$ & $\cdot$ & $\cdot$ & · & $\cdot$ & $\cdot$ & a & . \\
\hline M & AF481866 & $\cdot$ & $\cdot$ & . & $\mathrm{g}$ & $\cdot$ & $\cdot$ & . & . & $\cdot$ & $\cdot$ & g & $\cdot$ & $\cdot$ & $\cdot$ & . \\
\hline $\mathrm{N}$ & AF289285 & . & $\cdot$ & . & $\mathrm{g}$ & $\cdot$ & $\cdot$ & . & . & . & $\cdot$ & . & . & . & $\mathrm{a}$ & . \\
\hline $\mathrm{O}$ & - & $\cdot$ & $\cdot$ & . & $\mathrm{g}$ & $\cdot$ & $\mathrm{a}$ & . & . & $\cdot$ & $\cdot$ & . & $\cdot$ & . & a & . \\
\hline $\mathrm{P}$ & AF481874 & $\mathrm{c}$ & $\cdot$ & . & $\mathrm{g}$ & $\cdot$ & $\cdot$ & $\mathrm{t}$ & . & . & $\cdot$ & g & $\cdot$ & . & $\cdot$ & . \\
\hline
\end{tabular}




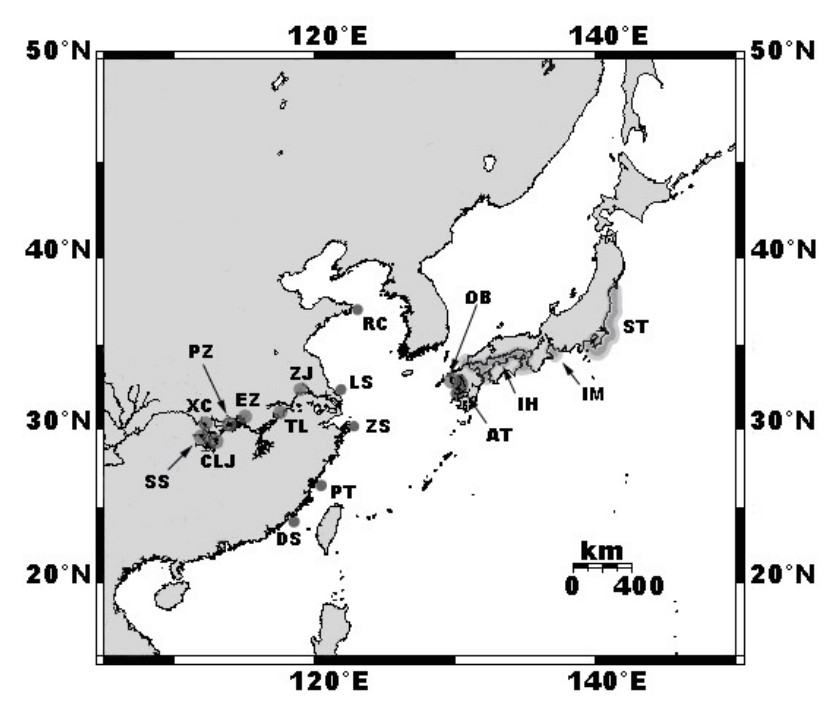

Figure 1. Distributional map of finless porpoise samples collected in this study. The positions of the sampling sits are marked by gray spots. Letters on the map present sampling localities. Data from Yoshida et al., 2001: ST $=$ Sendai Bay-Tokyo Bay; IM = Ise-Mikawa Bays; IH = Inland Sea-Hibiki Nada; AT = Ariake Sound-Tachibana Bay; OB = Omura Bay. Data from Yang et al., 2002: LS = Lusi; ZS = Zhoushan; PT = Pingtan; DS = Dongshan. Data from Zheng et al., 2005: $\mathrm{XC}=$ Xinchang; $\mathrm{SS}=$ Shishou; $\mathrm{CLJ}=$ Chenglingji; $\mathrm{PZ}=$ Paizhou; EZ = Ezhou; TL $=$ Tongling; $\mathrm{ZJ}=$ Zhenjiang. New sample collected: $\mathrm{RC}=$ Rongcheng. The base map was created by Online Map Creations [www.geomar.de/].

\section{Data analysis}

Sequences were edited and manually aligned using the DNASTAR software (DNASTAR Inc., Madison, WI, USA). After truncating them to $344 \mathrm{bp}$ to accommodate the published short sequences of Japanese populations, a minimum-spanning haplotype network was estimated using the TCS v1.21 program (Clement et al., 2000), which implemented the statistical parsimony method of Templeton et al. (1992). The haplotype network was nested into increasingly inclusive clades (or nestings) by following the rules described by Templeton et al. (1987) and Templeton and Sing (1993) in order to infer historical and ongoing processes responsible for the observed patterns of significant association between geography and nested haplotypes. The GeoDist v2.5 program (Posada et al., 2000) accounted for gene genealogies, haplotype frequencies, and geographical distribution of haplotypes to discriminate between historical events (such as fragmentation or range expansion events) and ongoing processes (such as gene flow). The interpretation of the results followed the inference key for the nested haplotype tree analysis of geographical distance (GEODIS; http://darwin.uvigo.es/software/geodis.html). All procedures were automatically performed by the ANeCA 1.1 software (Panchal, 2007), including the tasks of TCS v.21 and GeoDist v2.5, which were integrated into ANeCA v1.1.

\section{RESULTS}

A nested cladogram was constructed as shown in Figures 2 and 3. Haplotype C was 
located in the central position of the minimum spanning network (Figure 2), and was the most common haplotype possessed by most individuals (110) and populations (4 of 7 populations; Table 2). Haplotypes F, G, and H, which were exclusive to the Ariake Sound-Tachibana Bay population, comprised the clade 1-1. Most of the K, L, N, or O haplotypes were restricted to a single sampling site within ranges inhabited by individuals of the Yellow Sea-type, which comprised the clade 1-3. Yangtze population individuals possessed mostly M and P haplotypes and comprised clade 1-2, with only 1 individual collected from the Yellow Sea (Table 2 ). Clade 1-1 and haplotype A, together, formed clade 2-1. Clades 1-2, 1-4, and 1-5 formed clade 2-2, and clade 1-3 and haplotype J comprised clade 2-3 (Table 3, Figure 3). All 3 (2-step) clades were linked together without interior or tip status.

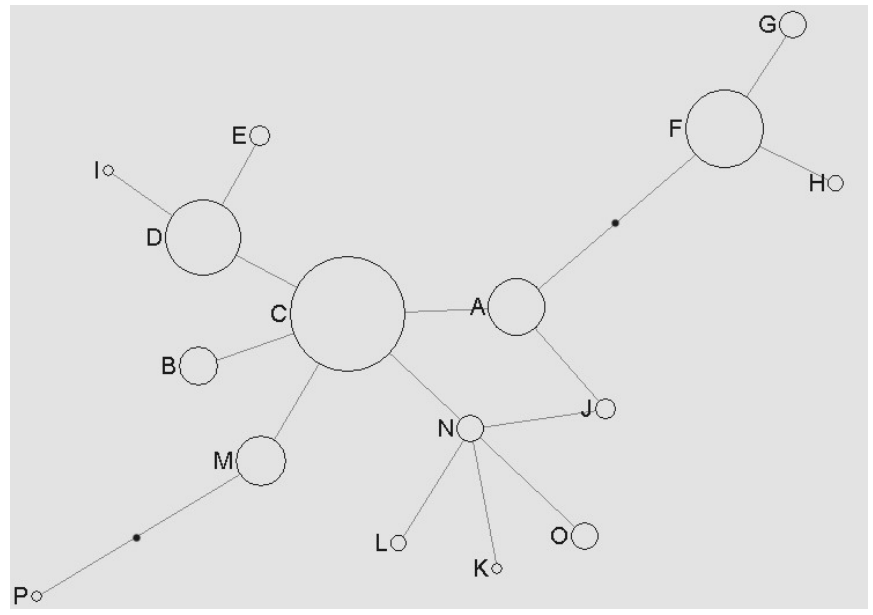

Figure 2. Phylogenetic network of 16 finless porpoise haplotypes. Circles are proportional to the number of calves presented and black dots present hypothetical haplotypes. The network was estimated under the $95 \%$ statistical limits of parsimony using the algorithm in Templeton et al. (1992).

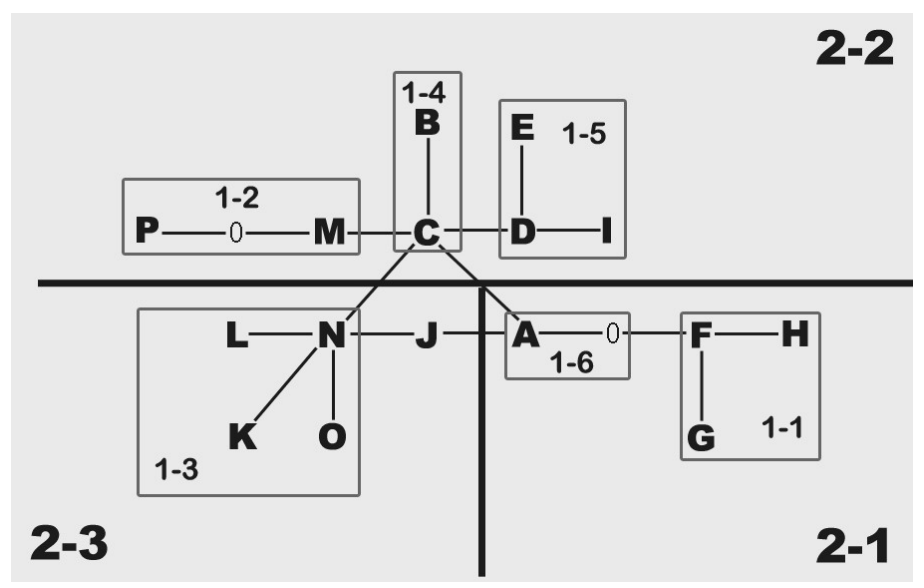

Figure 3. Maximum parsimony network and corresponding nested design for mtDNA control region haplotypes recognized in Table 1. Hypothetical haplotypes are presented by " 0 ". Thin-lined polygons enclose 1-step clades and are designated by " $1-n$ ". The thick lines separate 2 -step clades (2-1, 2-2, and 2-3). 
Table 2. Sample distributions of $16 \mathrm{mtDNA}$ control region haplotypes of finless porpoise in 17 sampling sites.

\begin{tabular}{|c|c|c|c|c|c|c|c|c|c|c|c|c|c|c|c|c|c|c|}
\hline \multirow[t]{2}{*}{ Populations } & \multirow[t]{2}{*}{ Sampling sites } & \multicolumn{16}{|c|}{ Haplotype } & \multirow[t]{2}{*}{ Total } \\
\hline & & $\mathrm{A}$ & $\mathrm{B}$ & $\mathrm{C}$ & $\mathrm{D}$ & $\mathrm{E}$ & $\mathrm{F}$ & G & $\mathrm{H}$ & I & $\mathrm{J}$ & $\mathrm{K}$ & $\mathrm{L}$ & $\mathrm{M}$ & $\mathrm{N}$ & $\mathrm{O}$ & $\mathrm{P}$ & \\
\hline Sendai -Tokyo Bay ${ }^{\mathrm{a}}$ & Sendai Bay-Tokyo Bay & 7 & 7 & & & & & & & & & & & & & & & 14 \\
\hline Ise-Mikawa Bays ${ }^{\mathrm{a}}$ & Ise-Mikawa Bays & & 4 & 52 & & & & & & & & & & & & & & 56 \\
\hline \multirow[t]{2}{*}{ Inland Sea-Hibiki Nada-Omura Bay ${ }^{\mathrm{a}}$} & Inland Sea Hibiki Nada & & & & 27 & 3 & & & & & & & & & & & & 30 \\
\hline & Omura Bay & & & & 8 & & & & & & & & & & & & & 8 \\
\hline Ariake Sound-Tachibana Bay ${ }^{\mathrm{a}}$ & Ariake Sound-Tachibana Bay & & & & 9 & & 46 & 6 & 2 & 1 & 1 & & & & & & & 65 \\
\hline \multirow{3}{*}{ Yellow Sea ${ }^{\mathrm{b}}$} & Lusi & 1 & & 4 & & & & & & & 1 & 1 & 2 & 1 & 5 & & & 15 \\
\hline & Rongcheng & 2 & & 2 & & & & & & & & & & & & 6 & & 10 \\
\hline & Zhoushan & & & 2 & & & & & & & 1 & & & & & & & 3 \\
\hline \multirow[t]{2}{*}{ South China Sea } & Pingtan & 7 & & 8 & & & & & & & & & & & 1 & & & 16 \\
\hline & Dongshan & 9 & & 23 & & & & & & & & & & & 1 & & & 33 \\
\hline \multirow[t]{7}{*}{ Yangtze River $^{d}$} & Xinchang & & & & & & & & & & & & & 4 & & & & 4 \\
\hline & Shishou & & & & & & & & & & & & & 8 & & & & 8 \\
\hline & Chenglingji & & & 2 & & & & & & & & & & & & & & 2 \\
\hline & Paizhou & & & 5 & & & & & & & & & & & & & & 5 \\
\hline & Ezhou & & & 3 & & & & & & & & & & 4 & & & 1 & 8 \\
\hline & Tongling & & & 4 & & & & & & & & & & 2 & & & & 6 \\
\hline & Zhenjiang & & & 5 & & & & & & & & & & 1 & & & & 6 \\
\hline Total & & 26 & & 110 & 44 & 3 & 46 & 6 & 2 & 1 & 3 & 1 & 2 & 20 & 7 & 6 & 1 & 289 \\
\hline
\end{tabular}

${ }^{a}$ Population of Inland Sea-Hibiki Nada and Omura Bay defined by Yoshida et al. (2001). ${ }^{\text {b}}$ Yellow Sea population. 'South China Sea population. ${ }^{d}$ Yangtze River population (Yang et al., 2002).

\begin{tabular}{|c|c|}
\hline Clade & Permutational chi-square statistic \\
\hline $1-2$ & 3.36 \\
\hline $1-3$ & 17.71 \\
\hline $1-4$ & 76.06* \\
\hline $1-5$ & 5.67 \\
\hline $2-1$ & $80.00^{*}$ \\
\hline $2-2$ & $328.59 *$ \\
\hline $2-3$ & 12.31 \\
\hline Entire cladogram & $296.53 *$ \\
\hline
\end{tabular}

Clades not showing genetic or geographical variations were excluded. *Significant at the 0.05 level.

The significance of clade distance and nested clade distance is shown in Figure 4. The past events inferred by following the inference key are listed in Table 4. Clades $1-2,1-5$, and 2-3 were not considered to be geographically associated, whereas clades 1-3 and 2-1 were inferred to be of restricted gene flow due to isolation by distance. Interestingly, the 2 special populations (Ariake Sound-Tachibana Bay and the Yellow Sea) that primarily had haplotypes of clades 2-1 and 1-3, respectively, had the highest nucleotide and haplotype diversity, respectively (Guo, 2006). Clade 1-4 was inferred to be of restricted gene flow with some long-distance dispersal over intermediate areas that were not occupied by the species, or past gene flow followed by extinction of intermediate populations. Clade 2-2 was inferred to be of long-distance colonization and/or past fragmentation. 


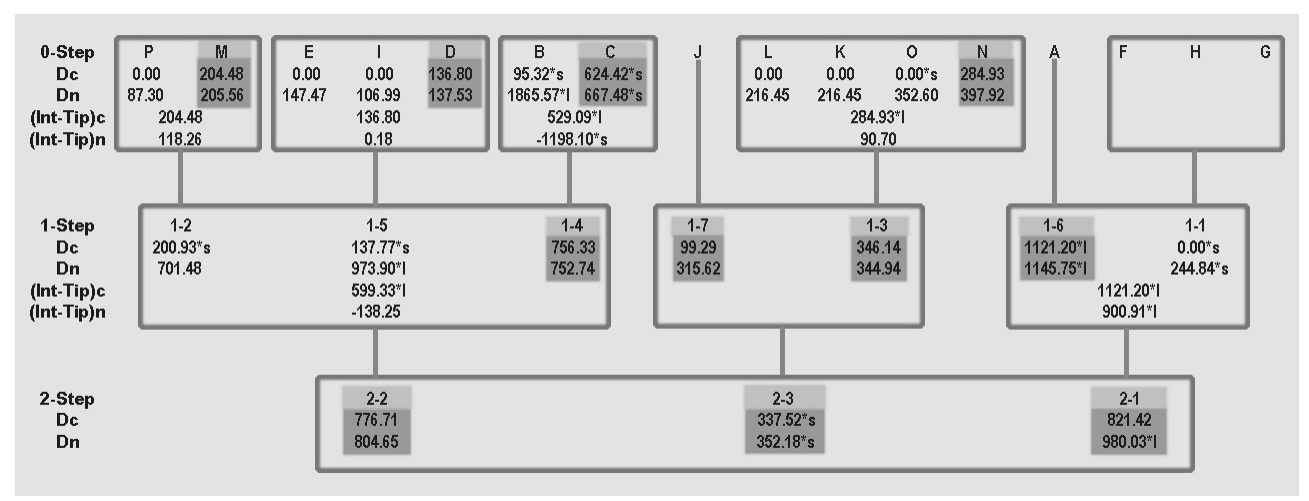

Figure 4. Nested cladistic analysis of geographical distance for the mtDNA haplotypes of finless porpoise. The haplotype designations are given at the top and are boxed together to reflect the 1-step nested design given in Figure 3. Higher level clade designations are given as one moves down the figure, with boxed groupings indicating the nesting structure. Immediately below each clade designation are the clade (Dc) and nested clade distances (Dn), respectively. An "s" marked behind indicates that the distance is significantly small at the $5 \%$ level, and an "l" indicates that it is significantly large. The clade name and distances are shaded for interior clades. At the bottom of the boxes that indicate the nested groups containing both tip and interior clades, the lines indicated by the symbols "(Int-Tip)c" and "(Int-Tip)n" give the average difference in distance between interior and tip clades within the nested group for clade distances and nested clade distances, respectively.

Table 4. Demographic inferences from the nested clade distance analysis (Templeton et al., 1995; Templeton, 1998) in finless porpoise populations.

\begin{tabular}{|c|c|c|}
\hline Clade & Inference chain & Inferred pattern \\
\hline $\begin{array}{l}\text { Haplotypes nested } \\
\text { in } 1-2\end{array}$ & $1-\mathrm{No}$ & The null hypothesis of no geographical association of haplotypes cannot be rejected \\
\hline $\begin{array}{l}\text { Haplotypes nested } \\
\text { in } 1-3\end{array}$ & $1-2-3-4-\mathrm{No}_{0}$ & Restricted gene flow with isolation by distance \\
\hline $\begin{array}{l}\text { Haplotypes nested } \\
\text { in } 1-4\end{array}$ & $1-2-3-5-6 *-7-8-Y e s$ & $\begin{array}{l}\text { Restricted gene flow/dispersal but with some long-distance dispersal over intermediate areas not } \\
\text { occupied by the species; or past gene flow followed by extinction of intermediate populations. }\end{array}$ \\
\hline $\begin{array}{l}\text { Haplotypes nested } \\
\text { in } 1-5\end{array}$ & $1-\mathrm{No}$ & The null hypothesis of no geographical association of haplotypes cannot be rejected \\
\hline $\begin{array}{l}\text { One-step clades } \\
\text { nested in } 2-1\end{array}$ & $1-2-3-4-$ No & Restricted gene flow with isolation by distance \\
\hline $\begin{array}{l}\text { One-step clades } \\
\text { nested in } 2-2\end{array}$ & $1-2-3-5-15-\mathrm{No}$ & Long-distance colonization and/or past fragmentation (not necessarily mutually exclusive) \\
\hline $\begin{array}{l}\text { One-step clades } \\
\text { nested in } 2-3\end{array}$ & 1-No & The null hypothesis of no geographical association of haplotypes cannot be rejected \\
\hline $\begin{array}{l}\text { Two-step clades nested } \\
\text { in the entire cladogram }\end{array}$ & $1-2-\mathrm{IO}$ & I-T status undetermined: inconclusive outcome \\
\hline
\end{tabular}

*Too few clades $(\leq 2)$ to determine concordance; $\mathrm{IO}=$ tip/interior status cannot be determined.

\section{DISCUSSION}

The sampling range covered most habitats of the finless porpoise in this study. The central-positioned (Figure 2), broadly spread and most common haplotype C (Table 2) in samples was likely the most ancient haplotype of all of those that were sampled (Takahata, 1988; Crandall and Templeton, 1993). Our results indicated that the ancient population with haplotype $\mathrm{C}$ expanded to different areas (suggested by the population expansion hypothesis of Guo, 2006) and mutated to contain other haplotypes. Gene flow had been retarded by geo- 
logical barriers that were changed during glacial cycles; thus, the mutants remained endemic. In clade 1-4, haplotype $\mathrm{C}$ expanded to the Ise-Mikawa Bay and mutated to B. Subsequently, a large land bridge connected the Asian continent, Taiwan, the Ryukyus, and Japan 1.3-1.6 mya (Kimura, 2000), which led to extinction of the animals in the intermediate areas. After the submerging of these land bridges, habitat fidelity behavior and/or other restricting factors restrained the re-mixing of finless porpoise populations and the divergence pattern has since been maintained.

In addition to clade 1-4, similar causes formed the divergence pattern of clade 2-2. An ancient population with haplotype $\mathrm{C}$ expanded to the Yangtze River and then mutated to $\mathrm{M}$ and $\mathrm{P}$. The $\mathrm{D}, \mathrm{E}$, and I haplotypes of the inland sea and post-arc marginal seawaters (Inland Sea-Hibiki Nada, Omura, and Ariake Sound-Tachibana Bay) mutated from C of the ancestral population. According to NCPA inference, allopatric fragmentation occurred in the ancestral population and left the residual forming populations inhabiting the Pacific coasts of the Japanese (Sendai-Tokyo and Ise-Mikawa Bay; clade 1-4), inland sea and post-arc marginal sea coasts of Japan (Inland Sea-Hibiki Nada, Omura, and Ariake Sound-Tachibana Bay; clade 1-5), and the Yangtze River (clade 1-2).

Individuals of the Ariake Sound-Tachibana Bay exclusively comprised clade 1-1, and clade 2-1 was mostly comprised of Ariake Sound-Tachibana Bay individuals. Similarly, clade 2-3 was primarily comprised of Yellow Sea individuals. The highly endemic haplotypes, along with high genetic diversity (nucleotide or haplotype diversity; Guo, 2006), suggested a relatively isolated state in these locations during the evolutionary history of the finless porpoise (Cox and Moore, 2000). This phenomenon explained the NCPA-derived inferences of restricted gene flow within clades 2-1 and 2-3. The historical reasons for their isolation are still undetermined. As no interior or tip status was determined in all of the 2-step clades, the divergent factors of clades 2-3 and 2-1 could not be inferred by NCPA in this study. Further studies including additional genome sequence data or more individuals to cover broader distributions should be more conclusive.

\section{ACKNOWLEDGMENTS}

Research supported by the National Natural Science Foundation of China (\#30901098, and \#31272646).

\section{REFERENCES}

Amato ML, Brooks RJ and Fu J (2008). A phylogeographic analysis of populations of the wood turtle (Glyptemys insculpta) throughout its range. Mol. Ecol. 17: 570-581.

Clement M, Posada D and Crandall KA (2000). TCS: a computer program to estimate gene genealogies. Mol. Ecol. 9: $1657-1659$.

Contreras-Días HG, Moya O, Oromí P and Juan C (2003). Phylogeography of the endangered darkling beetle species of Pimelia endemic to Gran Canaria (Canary Islands). Mol. Ecol. 12: 2131-2143.

Cox CB and Moore PD (2000). Biogeography: An Ecological and Evolutionary Approach. 6th edn. Blackwell Publishing, London.

Crandall KA and Templeton AR (1993). Empirical tests of some predictions from coalescent theory with applications to intraspecific phylogeny reconstruction. Genetics 134: 959-969.

Gao AL and Zhou KY (1995a). Geographical variation of external measurements and three subspecies of Neophocaena phocaenoides in Chinese waters. Acta Theriol. Sin. 15: 81-72.

Gao AL and Zhou KY (1995b). Geographical variation of skull among the populations of Neophocaena phocaenoides in 
Chinese waters. Acta Theriol. Sin. 15: 161-169.

Gao AL and Zhou KY (1995c). Geographical variations of postcranial skeleton among the populations of Neophocaena in Chinese waters. Acta Theriol. Sin. 15: 246-253.

Guo L (2006). Mitochondrial Phylogeography and Population History of Finless Porpoises in Sino-Japanese Waters and Temporal Change in Genetic Diversity of Finless Porpoises in Chinese Waters. Master's thesis, Nanjing Normal University, Nanjing.

Hammer MF, Karafet T, Rasanayagam A, Wood ET, et al. (1998). Out of Africa and back again: nested cladistic analysis of human Y chromosome variation. Mol. Biol. Evol. 15: 427-441.

Huang SF and Lin TP (2006). Nested phylogeographical clade analysis of Trochodendron aralioides (Trochodendraceae) in Taiwan. Taiwania 51: 64-67.

Imbrie J, Boyle EA, Clemens SC, Duffy A, et al. (1992). On the structure and origin of major glaciation cycles 1. Linear responses to Milankovitch forcing. Paleoceanography 7: 701-738.

Jefferson TA, Leatherwood S and Webber MA (1993). FAO Species Identification Guide. Marine Mammals of the World. FAO, Rome.

Kimura M (2000). Paleogeography of the Ryukyu Islands. Tropics 10: 5-24.

Lambeck K, Esat TM and Potter E-K (2002). Links between climate and sea levels for the past three million years. Nature 419: 199-206.

Liu JX (2006). Molecular Phylogeography of Four Marine Fishes in Northwestern Pacific. Ph.D. thesis, Ocean University of China, Qingdao.

Márquez LM, Van Oppen MJ, Willis BL, Reyes A, et al. (2002). The highly cross-fertile coral species, Acropora hyacinthus and Acropora cytherea, constitute statistically distinguishable lineages. Mol. Ecol. 11: 1339-1349.

Panchal M (2007). The automation of Nested Clade Phylogeographic Analysis. Bioinformatics 23: 509-510.

Paulo OS, Jordan WC, Bruford MW and Nichols RA (2002). Using nested clade analysis to assess the history of colonization and the persistence of populations of an Iberian Lizard. Mol. Ecol. 11: 809-819.

Posada D, Crandall KA and Templeton AR (2000). GeoDis: a program for the cladistic nested analysis of the geographical distribution of genetic haplotypes. Mol. Ecol. 9: 487-488.

Takahata N (1988). The coalescent in two partially isolated diffusion populations. Genet. Res. 52: 213-222.

Templeton AR (1998). Nested clade analyses of phylogeographic data: testing hypotheses about gene flow and population history. Mol. Ecol. 7: 381-397.

Templeton AR and Sing CF (1993). A cladistic analysis of phenotypic associations with haplotypes inferred from restriction endonuclease mapping. IV. Nested analyses with cladogram uncertainty and recombination. Genetics 134: 659-669.

Templeton AR, Boerwinkle E and Sing CF (1987). A cladistic analysis of phenotypic associations with haplotypes inferred from restriction endonuclease mapping. I. Basic theory and an analysis of alcohol dehydrogenase activity in Drosophila. Genetics 117: 343-351.

Templeton AR, Crandall KA and Sing CF (1992). A cladistic analysis of phenotypic associations with haplotypes inferred from restriction endonuclease mapping and DNA sequence data. III. Cladogram estimation. Genetics 132: 619-633.

Templeton AR, Routman E and Phillips CA (1995). Separating population structure from population history: a cladistic analysis of the geographical distribution of mitochondrial DNA haplotypes in the tiger salamander, Ambystoma tigrinum. Genetics 140: 767-782.

Turner TF, Trexler JC, Harris JL and Haynes JL (2000). Nested cladistic analysis indicates population fragmentation shapes genetic diversity in a freshwater mussel. Genetics 154: 777-785.

Weiss S, Persat H, Eppe R, Schlötterer C, et al. (2002). Complex patterns of colonization and refugia revealed for European grayling Thymallus thymallus, based on complete sequencing of the mitochondrial DNA control region. Mol. Ecol. 11: $1393-1407$.

Wilke T and Pfenninger M (2002). Separating historic events from recurrent processes in cryptic species: phylogeography of mud snails (Hydrobia spp.). Mol. Ecol. 11: 1439-1451.

Yang G, Ren WH, Zhou KY, Liu S, et al. (2002). Population genetic structure of finless porpoise, Neophocaena phocaenoides, in Chinese waters, inferred from mitochondrial control region sequences. Mar. Mamm. Sci. 18: 336-347.

Yoshida H, Shirakihara K, Shirakihara K and Takemura A (1995). Geographic variation in the skull morphology of the finless porpoise Neophocaena phocaenoides in Japanese waters. Fish. Sci. 61: 555-558.

Yoshida H, Yoshioka M, Shirakihara M and Chow S (2001). Population structure of finless porpoises (Neophocaena phocaenoides) in coastal waters of Japan based on mitochondrial DNA sequences. J. Mammal. 82: 123-130.

Zheng JS, Xia JH, He SP and Wang D (2005). Population genetic structure of the Yangtze finless porpoise (Neophocaena phocaenoides asiaeorientalis): implications for management and conservation. Biochem. Genet. 43: 307-320. 